Det vita fältet III. Samtida forskning om högerextremism

specialnummer av Arkiv. Tidskrift för sambällsanalys, nr 5 (2016)

\title{
Begreppet extremism - en kritisk introduktion
}

\section{Adrienne Sörbom \& Magnus Wennerhag}

SAMMANDRAG: Termen "extremism" har blivit vanligare inom både svensk offentlig debatt och myndighetsprosa. I sådana sammanhang är det dock sällan klart exakt vad som avses med denna term. Inte heller inom samhällsvetenskapen är begreppet extremism oomstritt och inom olika forskningsfält används begreppet på olika sätt. Syftet med Adrienne Sörbom och Magnus Wennerhags artikel är att belysa extremismbegreppets uppkomst och förändrade betydelse under moderniteten, samt att diskutera några av de problem som begreppet är behäftat med. Med hjälp av bland annat vetenskapssociologen Thomas F. Gieryns begrepp "gränsdragningsarbete" (boundary-work) visar Sörbom och Wennerhag hur begreppet extremism används i fältet mellan vetenskap, politik och samhällsdebatt. Författarnas huvudsakliga poäng är att begreppets utgångspunkt i en tydligt normativ föreställning om politiska avvikelser gör det mindre användbart i vetenskapliga sammanhang, eftersom det enbart tar dessa avvikelser för givna och inte erbjuder några förklaringar om varför de uppkommer eller vilken roll de spelar $\mathrm{i}$ moderna samhällen.

NYCKELORD: extremism; avvikelse; radikalisering; gränsdragningsarbete; demokrati; normativitet.

PUBLICERINGSHISTORIK: Originalpublicering.

ADRIENNE SÖRBOM är docent i sociologi vid Södertörns högskola.

E-POSTADRESS: adrienne.sorbom@sh.se

MAGNUS WENNERHAG är lektor i sociologi vid Södertörns högskola.

E-POSTADRESS: magnus.wennerhag@sh.se

FÖRSLAG PÅ KÄLLANGIVELSE:

Sörbom, Adrienne \& Magnus Wennerhag (2016) ”Begreppet extremism - en kritisk introduktion", i Det vita fältet III. Samtida forskning om högerextremism, specialnummer av Arkiv. Tidskrift för samhällsanalys, nr 5, s. I5-37.

DoI: http://dx.doi.org/IO.I3068/2000-62I7.5.I

(C) Författarna/Arkiv förlag \& tidskrift 20 I6 (publicerad I8 april 20ı6)

Artikeln distribueras enligt en upphovsrättslicens från Creative Commons:

Erkännande-Ickekommersiell-IngaBearbetningar 3.0 Unported, som medger fri ickekommersiell användning och spridning i oförändrat skick så länge källan anges. 
Arkiv. Tidskrift för samhällsanalys är en sakkunniggranskad vetenskaplig tidskrift för samhällsvetenskap och historia. Samtliga artiklar publiceras fritt tillgängliga på:

$$
\text { www.tidskriftenarkiv.se }
$$

(beständig länk, DoI: http://dx.doi.org/IO.I3068/2000-62I7)

Den här artikeln finns tillgänglig i följande format:

PDF \& HTML: via beständig länk, DOI: http://dx.doi.org/IO.I3068/2000-62I7.5.I EPUB: ingår i e-boksutgåva av numret, ISBN: 978 9I 79242763

TRYCK: ingår i bokutgåva av numret, ISBN: 978 9I 7924277 O

Grafisk utformning och sidnumrering är identisk i pdf och tryck.

Samtliga artiklar i nr 5 (20I6), Det vita fältet III. Samtida forskning om högerextremism, nås via beständig länk, DoI: http://dx.doi.org/IO.13068/2000-6217.5

$$
\text { Redaktion För nUmRet: Mats Deland, Paul Fuehrer, }
$$

Fredrik Hertzberg och Thomas Hvitfeldt

Arkiv. Tidskrift för sambällsanalys ISSN: 2000-62I7 (för elektronisk resurs)

ISSN: 2000-6225 (för tryckta nummer)

ges ut av

Stiftelsen Arkiv för främjande och spridning av samhällsvetenskaplig och historisk forskning

genom

Arkiv förlag \& tidskrift

Box 1559

SE-22I OI Lund

BESÖK: L Gråbrödersg 3 c, ipg

TEL: O46-I3 3920

ARKIV FÖRLAG: arkiv@arkiv.nu·www.arkiv.nu

TIDSKRIFTEN ARKIV: red@tidskriftenarkiv.se · www.tidskriftenarkiv.se

ANSVARIg UTGIVARE \& CHEFREDAKTÖR: Sven Hort

ADMINistrativ RedAKTÖr: David Lindberg

RedAKtörer: Paavo Bergman, Lisa Kings, Zhanna Kravchenko 


\section{Begreppet extremism \\ - en kritisk introduktion}

\section{ADRIENNE SÖRBOM \& MAGNUS WENNERHAG}

Inom svensk offentlig debatt tycks termen "extremism" ha blivit vanligare på senare tid. När termen används för att beskriva inhemska förhållanden avses oftast grupper av aktivister som har sin ideologiska hemvist inom nazistiska, fascistiska och nationalistiska idéströmningar, radikal islamism, eller olika varianter av anarkism, autonomism och kommunism. Vid sidan av beskrivningar som utgår från ideologi, brukar "extremism” också användas för att beteckna aktivistgrupper som använder våldsamma (eller andra olagliga) metoder för att uppnå sina mål. Inte sällan är det samma slags grupper som avses, oavsett om "extremism" betraktas som ett uttryck för gruppernas ideologi eller deras val av metoder.

Även i svensk myndighetsprosa har termen "extremism” börjat förekomma under senare år. Det främsta exemplet är regeringens tillsättande av en nationell samordnare "för att värna demokratin mot våldsbejakande extremism" (Dir. 20I4:IO3), som har till syfte att samordna lokala och nationella preventiva åtgärder för att motverka i synnerhet ungdomars rekrytering till ovan nämnda aktivistgrupper. Tillsättandet av denna samordnare föregicks av en utredning (SOU 20I3:8I). Denna utredning kritiserades av olika remissinstanser (såväl lärosäten som civilsamhällesorganisationer) för att vara bristfälligt förankrad i befintlig forskning och för att innebörden i utredningens centrala begrepp - "extremism" 
- var alltför otydligt definierad. ${ }^{\mathrm{I}}$ Detta ansågs kunna leda till rättsosäkerhet och gränsdragningsproblem vid myndigheters tillämpning av de föreslagna åtgärderna, särskilt eftersom det var oklart huruvida det var individers eller gruppers ideologi eller deras (våldsamma eller olagliga) politiska metoder som skulle betraktas som indikatorer på att de riskerade bli "extremister". Vidare påtalades risken för målkonflikter mellan utredningens förslag och andra centrala statliga politikområden, till exempel främjande av ungdomars politiska engagemang, samt värnandet av grundlagsfästa medborgerliga rättigheter som yttrande- och organisationsfrihet.

Detta exempel kan ses som en illustration på att det även i liberaldemokratiska rättsstater uppstår kontroverser kring statens hanterande av politiska dissidenter, det vill säga personer vars politiska övertygelse avviker från de som dominerar i ett specifikt samhälle. Grunden för sådana kontroverser är det uppenbara dilemma som den demokratiska rättsstaten ställs inför i lägen när staten anser sig behöva göra begränsningar i de medborgerliga rättigheterna, antingen för specifika grupper eller avseende specifika beteenden. Å ena sidan ska en demokratisk stat kunna garantera sina medborgare yttrande- och organisationsfrihet, å andra sidan måste staten kunna garantera den allmänna ordningen. Dilemmat blir särskilt tydligt i lägen när sådana begränsningar görs med hänvisning till att det demokratiska systemet måste kunna försvara sig mot dem som anses hota själva styrelseskicket, eller kunna skydda specifika grupper - såväl utsatta minoritetsgrupper som statens representanter - från hot och våld. Inget demokratiskt samhälle har helt kunnat lösa detta dilemma, och de gränsdragningar som görs blir i slutändan alltid beroende av politikens och det omgivande samhällets dominerande värderingar och maktförhållanden.

Mycket talar för att just termen "extremism" blivit alltmer central när denna typ av gränsdragningar i dag diskuteras i den offentliga debatten, eller när de omsätts i myndighetsutövning. Som ovan konstaterats är det dock sällan klart exakt vad som avses med denna term. Vi vill därför i

I. Artikelförfattarna skrev, tillsammans med statsvetaren Joakim Ekman, Södertörns högskolas kritiska remissvar på denna utredning. Andra kritiska remissvar inkom från exempelvis universiteten i Göteborg och Umeå. 
denna artikel bringa större reda i hur termen uppkommit och hur dess betydelse har förändrats under moderniteten. Artikeln kommer dock främst att fokusera den vetenskapliga användningen av begreppet "extremism". Till skillnad från politikens mer godtyckliga gränsdragningar, är vetenskapens krav på hur begrepp definieras och används vanligen mer strikta. Detta gäller även begrepp för samhällsfenomen som trots att de kanske är begränsade till specifika samhällstyper och historiska epoker måste kunna vara allmänt tillämpbara. Samtidigt går inte samhällsvetenskapliga begrepps betydelse och användning att isolera från sin samhälleliga kontext. Många gånger bildas vetenskapliga begrepp utifrån redan etablerade termer från politik och samhällsliv, parallellt med att termerna används för att legitimera maktutövning och allmänna föreställningar. Åt andra hållet används också exempelvis vetenskapliga definitioner i den allmänna debatten för att motivera politiska ställningstaganden eller när de görs till utgångspunkt för konkret myndighetsutövning. Detta gäller även begreppet "extremism".

Vårt syfte med denna artikel är att utifrån några framstående teoretiker på området kasta ljus över hur extremistbegreppet etablerats inom vissa samhällsvetenskaper och över de definitioner som i dag är de dominerande, samt diskutera några av de problem som begreppet är behäftat med. I denna diskussion kommer vi delvis att använda oss av vetenskapssociologen Thomas F. Gieryns (1983) begrepp "gränsdragningsarbete" (boundary-work) för att belysa hur begreppet extremism används i fältet mellan vetenskap, politik och samhällsdebatt. Vår huvudsakliga poäng är att begreppets utgångspunkt i en tydligt normativ föreställning om politiska avvikelser gör det mindre användbart i vetenskapliga sammanhang, eftersom det enbart tar dessa avvikelser för givna och inte erbjuder några förklaringar om varför de uppkommer eller vilken roll de spelar i moderna samhällen. Detta innebär samtidigt att det även i politiska sammanhang blir problematiskt att använda begreppet med hänvisning till att det vilar på vetenskaplig grund. 


\section{Extremismbegreppet inom samhällsdebatt och vetenskap}

Inom den samhällsvetenskapliga forskningen är det i dag i synnerhet inom statsvetenskap och politisk sociologi som begreppet extremism används. Begreppet återfinns exempelvis i mer allmänna teorier om demokrati och demokratisering (t.ex. Lipset \& Raab 1970) men framför allt i forskning om politiska partier, där det används för att skilja olika partityper åt (t.ex. March \& Mudde 2005; March 20II; Mudde 20IO). I synnerhet i Tyskland har forskare dessutom försökt att etablera studiet av "extremism" som ett eget forskningsfält, för att studera olika politiska aktörer som uppfattas vara emot demokrati (se t.ex. Jesse \& Thieme 20II). Dessa strävanden har varit nära knutna till den tyska (ursprungligen den västtyska) statens konstitutionella projekt att aktivt försvara sig mot aktörer som uppfattas som hot mot den demokratiska ordning som etablerades i och med den nya förbundsrepublikens tillkomst efter andra världskriget. ${ }^{2}$ En av de tyska forskare som varit central för att etablera "extremismforskning" som ett eget fält är statsvetaren Uwe Backes. Hans bok Political Extremes (2010) ${ }^{3}$ utgör även ett av de få uttömmande försöken att kartlägga extremistbegreppets framväxt och precisera begreppets innebörd. Han kan därmed ses som en betydelsefull teoretiker inom detta forskningsfält. I vår beskrivning av begreppets framväxt och dominerande betydelser nedan kommer vi därför främst att utgå från Backes.

Föreställningen att vissa politiska idéer och handlingar är extrema är inte ny. I och med den franska revolutionen grundlades uppfattningen att det politiska landskapet var strukturerat av en kontinuerlig skala mellan höger och vänster, utifrån hur delegaterna var placerade i den beslutande församling som upprättades under revolutionsåren. I denna församling satt de politiker som mest långtgående ville infria revolutio-

2. Det uttryck som officiellt brukar användas för det tyska politiska systemets självförståelse av detta projekt är "streitbare Demokratie" - den stridbara demokratin. Själva uttrycket kommer från den tysk-judiske rättsvetaren Karl Löwenstein, som i exil i USA I937 publicerade en analys av orsakerna till Weimarrepublikens sammanbrott, i vilken han argumenterade för den demokratiska statens rätt att försvara sig själv mot "extremistiska" rörelser (Backes 20IO, s. I53 ff.).

3. Ursprungligen utgiven på tyska som Politische Extreme (2006). Alla sidhänvisningar till verket i denna text avser den engelska översättningen, men vid översättning av citat har den ursprungliga tyska utgåvan använts. 
nens krav på ökad jämlikhet och frihet till vänster, medan de politiker som ville se få eller inga förändringar satt till höger. Redan under I8ootalet ledde användningen av vänster-högerskalan inom fransk politik till uttryck såsom "extremhöger" och "extremvänster", vilka då helt enkelt syftade på de politiker som befann sig längst högerut respektive vänsterut på denna skala (Backes 20ı, s. 77 ff.).

Backes menar emellertid att den franska revolutionens uppdelning av politiska ståndpunkter utifrån en skala mellan vänster och höger inte är den enda källan till vår tids föreställningar om "det politiskt extrema". Han menar att även Aristoteles teorier om de olika styrelseskicken har påverkat denna föreställning, om än indirekt. För Aristoteles var det eftersträvansvärda styrelseskicket den blandade konstitution (politeia) som kombinerade monarki, aristokrati och demokrati (det vill säga fåtalsrespektive folkstyre), vilket ställdes i motsats till exempelvis tyranni eller anarki. Den blandade konstitutionen sågs som den måttfulla medelvägen, som stod i motsatsförhållande till de extrema styrelseformerna. I kretsar där sådana tankar var inflytelserika under I8oo-talet sågs höger-vänster inte som ett neutralt konstaterbart politiskt kontinuum, utan som två ytterligheter som stod i motsats till en måttfullhetens mittpunkt på skalan - som ansågs vara politiskt eftersträvansvärd i sig. De som argumenterade för den måttfulla medelvägen ansåg sig därmed stå i motsats till såväl revolution som reaktion (ibid., s. 79 ff., I75 ff.).

Även om orden "extremism" och "extremist" hade använts i olika sammanhang tidigare var det, enligt Backes, emellertid inte förrän under det tidiga 1900-talet som dessa termer fick en något bredare spridning inom politiska och vetenskapliga sammanhang. I ett brittiskt sammanhang kom orden under detta århundrades första år ibland att användas för att särskilja "extremister" från "moderata", inom de grupper som i den brittiska kolonin Indien förespråkade större självstyre. Men det var framför allt efter den ryska februarirevolutionen 1917 som beskrivningen började användas mer allmänt för rörelser och politiska partier. Först avsågs främst politiska aktörer på vänsterkanten, i synnerhet de ryska bolsjevikerna, men i och med de italienska fascisternas maktövertagande några år senare kom även politiska aktörer på högerkanten att benämnas på detta sätt (ibid., s. 97 ff., I76). 
Det var i synnerhet dessa och närbesläktade politiska inriktningar som under 1900-talet kom att benämnas som "extremistiska”. Speciellt efter andra världskriget och fascismens och nazismens nederlag (men även med anledning av kommunismens utbredning) formulerades olika teorier inom samhällsvetenskaperna för att kunna förklara varför dessa rörelser hade kunnat komma till makten. I sådana teorier återfanns ibland begreppet extremism, vid sidan av begrepp som "totalitarism" (Arendt 2016 [I95I]) eller "den auktoritära personligheten" (Adorno 1950). ${ }^{4}$ Den efterkrigstida teori som fick störst betydelse för förståelsen av extremistbegreppet är dock enligt Backes den som formulerades av de amerikanska politiska sociologerna Seymour M. Lipset och Earl Raab i boken The Politics of Unreason. Right-Wing Extremism in America, I790-1970 (1970). I denna studie utarbetar de båda forskarna en typologi där den politiska inriktningen hos olika typer av politiska rörelser ses som beroende av rörelsernas klassbas. Inom de tre olika klasser som diskuteras - överklass, medelklass och lägre klass - menar Lipset och Raab att såväl "moderata" som "extremistiska” ideologier kan produceras. Utifrån denna typologi betraktas sedan kommunism som den lägre klassens extremism och demokratisk socialism som dess moderata ideologi, fascism som medelklassens extremism och liberalism som denna klass moderata ideologi, och slutligen "traditionell auktoritarianism" som överklassens extremism och konservatism som dess moderata ideologi (Backes 20IO, s. I6I-I63).

Klasskomponenten i denna typologi har inte någon framträdande roll i dagens forskning om extremism, men Lipsets och Raabs definition av extremism har blivit desto viktigare:

Extremismens grundläggande ideologi ryms inom monismens modell. Extremism innebär sabotage av den demokratiska processen, genom handlingar eller genom påtryckningar. Med demokratisk politisk process avses i grund och botten demokratisk politisk pluralism: en "öppen demokratisk marknadsplats" för idéer, yttranden och harmoniskt politiskt handlande. Monism innebär att den demokratiska marknadsplatsen stängs, antingen av en stor majoritet eller av en minoritet som handlar föregripande (Lipset \& Raab I970, s. 428).

4. Adornos mer socialpsykologiska analys inriktade sig dock enbart på vad som urskildes som en specifik fascistisk personlighet. 
Utifrån detta sätt att begreppsliggöra extremism blir det centrala huruvida en politisk aktör är motståndare till politisk pluralism, det vill säga motsätter sig att den politiska gemenskapen hyser en mångfald av - och i konflikt stående - idéer, intressen och perspektiv. För Lipset och Raab betyder detta vidare att "extremism innebär överträdelse av de normativa procedurers gränser som utmärker den demokratiska politiska processen" (ibid., s. 7).

Medan Lipset och Raab främst fokuserar på politiska aktörers ideologi, görs det inom annan forskning en distinktion mellan aktörernas politiska målsättningar och de metoder de använder för att uppnå sina mål. Detta gäller exempelvis den samtida forskningen om politiska partier. I en artikel om radikala vänsterpartier i Europa menar den belgiske statsvetaren Cas Mudde och den brittiske statsvetaren Luke March att "i ett liberaldemokratiskt sammanhang [...] kan extremister definieras som antidemokrater per se, medan radikaler är antiliberaldemokratiska, men inte antidemokratiska per se" (March \& Mudde 2005, s. 24-25). I en senare text av Mudde (20I0, s. II68-II69), som diskuterar "populistiska radikalhögerpartier", menar han att "radikalism" kännetecknas av ett motstånd mot liberal eller konstitutionell demokrati (i synnerhet konstitutionella begränsningar av folksuveräniteten) kombinerat med en acceptans för proceduriell demokrati, medan "extremism" varken accepterar folksuveränitet eller proceduriell demokrati. Ytterligare andra forskare har menat att "extremism" handlar om motstånd mot demokratiska värderingar, medan "radikalism" handlar om motstånd mot demokratiska metoder (t.ex. Klingemann \& Pappi 1972, citerade i Backes 20Io, s. I64). Det som sammanför dessa definitioner av "extremism", är att extremism ställs i motsats till demokrati - oavsett om detta förstås som en uppsättning värderingar eller som en uppsättning av metoder för politisk påverkan och inflytande.

En något annorlunda begreppsanvändning finner vi hos den nederländske partiforskaren Paul Lucardie (20I4). I likhet med den aristoteliskt influerade idén om den blandade konstitutionen menar Lucardie att de flesta politiska system även i dag, de facto, utgör en blandning av demokratiska, aristokratiska och monarkiska element: 
I ett blandat styre fattas de flesta beslut av eliter, några av en enskild person, till exempel en vald president eller premiärminister, och ett fåtal av folket (genom allmänna val eller folkomröstningar) (Lucardie 20I4, s. I4).

Utifrån den modell som Lucardie skapar är extremister sådana aktörer som strävar efter att renodla den blandade konstitutionen, så att den enbart blir demokratisk, aristokratisk eller monarkisk. De grupper som i någon bemärkelse eftersträvar ett renodlat folkstyre betraktas som demokratiska extremister, medan de som vill se ett renodlat fåtals- eller envälde ses som monarkiska eller aristokratiska extremister. Utifrån Lucardies något annorlunda teoribygge betraktas därmed inte demokrati och extremism nödvändigtvis som varandras motsatser.

\section{Problemen med extremistbegreppet}

I sin summering av den forskning som i dag använder extremistbegreppet kommer Backes fram till att det vanligen är väldigt vagt definierat, samt att användningen av begreppet ofta skiljer sig åt forskare emellan (Backes 20IO, s. 179). Ett ytterligare problem som Backes identifierar är extremistbegreppets normativa slagsida. Trots att han själv argumenterar för begreppets användbarhet menar han att "extremism" tillhör en klass av beteckningar som ofta används både normativt och pejorativt:

De är stigmaord som används för att markera politiska legitimitetsgränser, för att utdöma ovärdighet och benämna faror. Utpekandet av det extrema är en del av normaliseringsdiskurser, i vilka majoritetssamhället ständigt återspeglar sin normalitet och sin mittenposition. [...] Den politiska majoritetskulturens användning av stigmaordet "extremism" skapar det som Reinhart Koselleck benämner en "asymmetrisk" språksituation. De utpekade kan inte acceptera den etikett de fått, de distanserar sig från den främmande beteckningen och betvivlar dess hållbarhet, de understryker dess brännmärkande karaktär och bestrider dess vetenskapliga förklaringsförmåga (Backes 20IO, s. I78).

Backes påpekar att historiskt sett har termen "extremist" utanför forskarvärlden (framför allt) använts för att stigmatisera och utdefiniera politiska grupper vars intressen står i motsättning till dem som för tillfället innehar den politiska makten, och ofta har detta skett utan att definiera vari dessa gruppers "extremism" består rent substantiellt. Om begreppet 
används på samma sätt inom vetenskapen - vars begrepp ska vara möjliga att tillämpa i olika sammanhang - finns det enligt Backes en risk att dess definition blir alltför relativistisk: "Enligt en sådan definition måste liberala regimmotståndare i diktaturer i regel betraktas som 'extremister"' (Backes 20IO, s. I80).

Denna kritik återfinns även hos Lucardie. Om extremism enbart definieras som en strävan att radikalt förändra det dominerande systemet - oavsett om detta är en liberaldemokrati eller en totalitär enpartistat riskerar begreppet inte bara att bli för relativistiskt, utan även att implicit betrakta status quo som det normala eller önskvärda (Lucardie 20I4, s. I2-I3). En annan typ av extremistdefinitioner som Lucardie ser som problematiska är sådana som främst fokuserar aktörernas val av metoder för att uppnå sina politiska målsättningar, oaktat vilka värderingar eller ideologiska målsättningar dessa handlingar syftar till att stärka eller värna:

Under extrema omständigheter kan även måttfulla personer bruka våld, exempelvis för att försvara sitt land mot utländska inkräktare eller kolonialmakter. [...] Analytiskt sett är det ganska meningslöst att definiera de moderata patrioter som bekämpade den nazistiska ockupationen i Frankrike, Belgien eller Norge 1940-1945 som "extremister" och fredliga anarkister eller nyfascister under efterkrigstiden som "moderater" eller "centrister" (Lucardie 20I4, s. I2).

Lucardie ser även problem med de begreppsliggöranden av extremism som implicit eller explicit kontrasterar det politiskt extrema med en specifik typ av demokrati. En sådan hållning ger exempelvis Luke March (20II, s. IO) explicit uttryck för i sin bok om radikala vänsterpartier i Europa: "Det är därför rimligare att definiera radikalism och extremism utifrån den liberala demokratins perspektiv, eftersom denna har blivit det enda existerande alternativet och är tillämplig på de flesta europeiska länder.” Ett sådant förhållningssätt erbjuder förvisso en större analytisk precision, och därigenom undviks vissa av de problem som mer relativistiska extremistbegrepp kan leda till, men samtidigt gör det begreppet tillämpbart enbart i vissa historiska och samhälleliga kontexter. Ett ytterligare problem som Lucardie uppmärksammar med denna typ av begreppsliggöranden är att inte heller extremismens motsats demokrati är ett oomstritt begrepp (Lucardie 20I4, s. I4). Även inom moderna 
liberala demokratier finns det en mängd skilda uppfattningar om vad demokrati är eller bör vara (se exempelvis Held 1997), och många gånger är det just dessa skilda synsätt på demokrati som kommer till uttryck i såväl sakfrågeorienterade som mer ideologiska politiska konflikter mellan partier, rörelser och intressegrupper.

Lucardies lösning för att undvika alla dessa problem blir (som vi sett ovan) att mer neutralt betrakta extremism som en aktörs vilja att renodla samhällets de facto blandade styre antingen i riktning mot ett rent folkstyre eller ett rent en- eller fåtalsvälde. Även Backes argumenterar, som vi strax ska se, för ett extremismbegrepp som delvis förhåller sig till den aristoteliskt inspirerade föreställningen om den blandade konstitutionen, men med helt andra utgångspunkter och en helt annorlunda modell som resultat.

\section{Backes definition av extremism}

I avslutningen till sin bok Political Extremes (2010) försöker Backes ta fasta på några av de grundläggande kännetecken för "extremism" som hävdats av många tidigare forskare, för att själv kunna formulera en mer uttömmande vetenskaplig definition av begreppet som inte enbart återspeglar sin egen tids dominerande föreställningar och maktförhållanden.

I likhet med Lipset och Raab betraktar Backes extremism som en strävan efter "monism", det vill säga ett motstånd till politisk pluralism och en vilja att eliminera konkurrens mellan olika åsikter, opposition och politiska skillnader överlag. Antitesen till extremism blir därmed den konstitutionella staten, det vill säga en rättsstat vars institutionella ordning garanterar medborgarnas rättigheter samt kontrollerar och begränsar makthavarnas förehavanden på ett förutsägbart sätt. Detta statsorienterade kriterium är emellertid inte tillräckligt: Backes menar även (med referens till den amerikanske statsvetaren Robert A. Dahl) att den konstitutionella staten måste vara en "polyarki", det vill säga ett system som förutsätter en mångfald av politiska partier och intressen som under fredliga former konkurrerar om inflytande, makt och politiska positioner. Dessutom bör denna de "politiska idéernas marknadsplats" kännetecknas av öppna och tillgängliga debatter och beslutsordningar som i praktiken 
möjliggör olika medborgares, partiers och intressegruppers deltagande i de politiska besluten. Även dessa aspekter ses som extremismens motsats, då extremister i stället anses sträva efter att koncentrera den politiska makten till ett fåtal för att utan insyn och kritik från andra kunna förverkliga sina idéer. Det som utmärker extremistiska ideologier, menar Backes, är nämligen en strävan efter enhet, endräkt och harmoni utifrån en förställning om att den egna världsåskådningen är den enda sanna, samt - på en socialpsykologisk nivå - en intolerans mot ambivalens och heterogenitet. Konsekvensen av dessa extremismens strävanden blir i slutändan att medborgarnas frihet och jämlikhet undermineras, genom strikta hierarkier mellan de styrande och de styrda (Backes 20I0, s. I8I-I84).

Backes begreppsliggörande av extremism utifrån dessa parametrar ger i förstone bilden av ett tydligt bipolärt strukturerat förhållande, inom vilket extremismens "monism" - enhetssträvanden, slutenhet, maktkoncentration och hierarkier - utgör den absoluta motsatsen till den konstitutionella rättsstatens "polyarki" - åsiktskonkurrens, rättsstatlighet och transparens, samt dess frihetsgaranterande och jämlika medborgarskap. Backes nöjer sig emellertid inte med en sådan enkel tudelad modell. För att tydligare kunna urskilja olika typer av "extremismer" introducerar han i stället två axlar: dels en "demokratiaxel", som anger graden av strävan efter jämlikhet, dels en "konstitutionalistisk axel", som anger graden av strävan efter självbestämmande. För en grafisk illustration av denna modell, se figuren på sidan 27 nedan.

I förhållande till Backes begreppsliggörande av extremism (som den konstitutionella statens motsats) kan det tyckas märkligt att den konstitutionalistiska axeln inte anger de politiska aktörernas grad av strävan efter "polyarki" och rättsstatlighet, utan i stället i vilken grad de eftersträvar självbestämmande, det vill säga hur mycket de anser att staten ska reglera politik och samhällsliv på bekostnad av individens självbestämmande. Detta är emellertid en konsekvens av att Backes uttryckligen ansluter sig till den aristoteliska tradition som han tidigare i sin bok lyfter fram som historiskt central för såväl politikens som vetenskapens förståelse av "det politiskt extrema". Det är alltså inte någon av denna axels ytterpunkter som ska förstås som extremismens motsats, utan dess medelpunkt. Det är här vi återfinner dem som strävar efter den konstitutionella och 
"polyarkiska" staten. De som utifrån denna axel betraktas som extremister är å ena sidan de som vill stärka statens makt och enhet - och drastiskt minska individernas utrymme för självbestämmande - till den grad att staten blir totalitär (till exempel fascism eller nazism och auktoritär kommunism), å andra sidan de som vill öka det individuella och kollektiva självbestämmandet till den grad att staten löses upp (till exempel anarkism och anarkokommunism) (Backes 20IO, s. 184-188).5

På samma sätt resonerar Backes kring demokratiaxeln. Även här föreställer han sig en demokratisk medelpunkt vars motsatser å ena sidan är de som accepterar eller bejakar omfattande ojämlikhet (till exempel fascism eller nazism), å andra sidan de som strävar efter total jämlikhet (till exempel anarkister och såväl auktoritära som anarkokommunister). Resonemanget han för är att den konstitutionella staten i dess moderna form är, och behöver vara, en blandad konstitution som inte bara innehåller demokratiska utan även monarkiska och aristokratiska element, som alla balanserar varandra (ibid., s. I84-185). Denna föreställning om en eftersträvansvärd medelpunkt som varken är för lite eller för mycket demokratisk kan tyckas något inkonsekvent, givet att Backes tidigare definierade extremism som ett uttryck för hierarkiska strävanden och den absoluta motsatsen till jämlikhet. Samtidigt blir det en ofrånkomlig konsekvens av införandet av en eftersträvansvärd medelpunkt i modellen.

Slutligen inför Backes även en tredje axel, "religionsaxeln", där ytterpunkterna utgörs av dem som eftersträvar teokratiska former av styre respektive dem som är direkt fientliga till religion. Även denna axel har en eftersträvansvärd mittpunkt, där religionsutövning tillåts och skyddas av staten men där ingen religion betraktas som politikens absoluta utgångspunkt. Den typ av extremism som därigenom ges en plats i Backes modellbygge är främst aktörer som förespråkar teokratiska styrelseformer, till exempel radikala former av islamism (ibid., s. I88-189). ${ }^{6}$

5. Även om Backes inte diskuterar detta, skulle man enligt hans modells logik kunna infoga ytterligare en form av "extremism", nämligen pro-kapitalistiska former av libertarianism, eftersom dessa likt anarkismen vill öka det individuella självbestämmandet och drastiskt minska statens inflytande. I figuren på nästa sida skulle detta slags aktörer i så fall placeras högst upp till höger.

6. Backes nämner här även auktoritär kommunism som islamismens motpol utmed religionsaxeln, med hänvisning till Sovjetstatens fientliga inställning till kyrka och religion. 
Figur. Den politiska extremismens former $i$ det tvådimensionella politiska rummet (antidemokrati och antikonstitutionalism)

KONSTITUTIONALISTISK AXEL

anarkisk

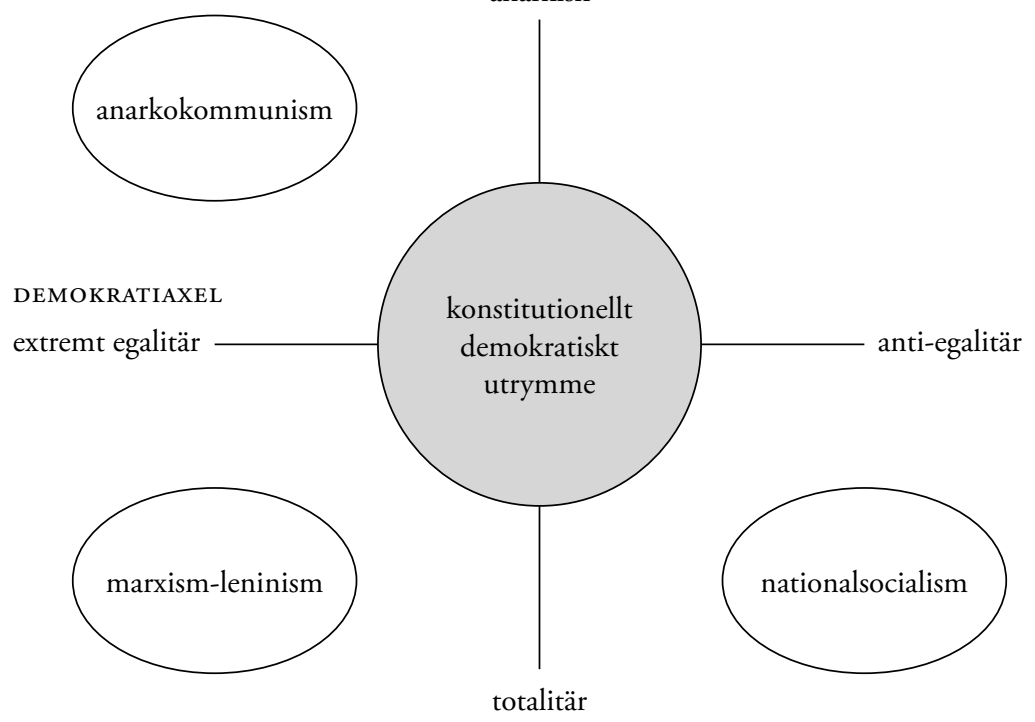

Figuren är hämtad från Backes (20I0, s. I87).

Trots att Backes har som uttryckligt syfte att erbjuda ett extremistbegrepp som inte enbart återspeglar ett specifikt samhälles dominerande föreställningar och maktförhållanden, bekräftar hans modell på många punkter just vad som skulle kunna ses som en dominerande tidsanda. De olika axlar som hans komplexa teoribygge utgår ifrån placerar de grupper som enligt vår tids common sense utgör "extremister" på ett sätt som främst bekräftar denna uppfattning. Det är också oklart huruvida modellen faktiskt förklarar något. Det som modellen främst visar är att den som alltför mycket avviker från de dominerande värderingarna $\mathrm{i}$ ett samhälle är en extremist, och att detta bottnar i att vissa värderingar antingen över- eller underbetonas i förhållande till den mittpunkt kring 
vilken majoritetens uppfattningar för tillfället är koncentrerade. Det är alltså en modell som främst kartlägger avvikelser från de normer som vid en given tidpunkt dominerar inom ett specifikt samhälle.

Den normativa föreställning om den eftersträvansvärda mittpunkten som Backes bygger sin modell på rimmar också illa med synsätt där konflikter mellan motsatta ideologier och intressen anses vara grundläggande för en välfungerande demokrati. Bland dem som formulerat sådana teorier finner vi till exempel Chantal Mouffe (2008) och hennes konfliktbetonande teori om "det politiska", men även Robert A. Dahl (se t.ex. Held I997, s. 249), som Backes själv åberopar när han framställer "polyarki" som "monismens" absoluta motsats.

En av de mest problematiska punkterna i Backes teoribygge är den roll han tillmäter den eftersträvansvärda medelpunkten inom politiken. I Hasse och Tages klassiska sketch "Centerextremisten" från 1973 (en drift med den svenska sjuttiotalsvänsterns många splittringar) spelar Gösta Ekman en utbrytare till Centerpartiet, som ser som sin främsta ideologiska ledstjärna att "vara extremt i mitten”. Det finns dock inte särskilt mycket som talar för att verkliga politiska aktörer - inte ens de som befinner sig i den politiska mittfåran - ser detta som utgångspunkten för sin politiska gärning. Politikens mittpunkt tenderar alltid att röra på sig, som ett resultat av förändrade styrkeförhållanden mellan de politiska aktörerna och även på grund av att partier, intresseorganisationer och rörelser ändrar sina politiska preferenser och de intressen de säger sig värna. Åsikter som inom en liberal demokrati vid en tidpunkt tillhör den politiska mittfåran kan årtionden senare anses mycket avvikande, och tvärtom. Betänk till exempel på hur synen på statligt ägande respektive HBTQ-personers rättigheter har förändrats under senare årtionden i Sverige. Givet det faktum att det moderna samhället alltid har utmärkts av en pågående diskussion om hur omfattande jämlikheten ska vara och i hur stor utsträckning staten ska tillåtas göra ingrepp i människors självbestämmande tycks Backes försök till att på vetenskaplig väg komma fram till modell som fastslår politikens eftersträvansvärda medelpunkt en smula övermodigt.

Vi finner inte heller $\mathrm{i}$ Backes teori något som stödjer den ibland $\mathrm{i}$ populära sammanhang hävdade föreställningen om att olika "extremis- 
mer" ytterst skulle kunna gå att härleda från en och samma typ av normer eller beteenden. Det enda som förenar "extremismerna" i Backes teori är att de avviker - och anses avvika - från de normer och beteenden som dominerar i ett visst samhälle vid en viss tidpunkt.

De uppenbara problemen med de olika försöken att definiera "det politiskt extrema" leder oss till frågan varför vetenskapen alls ska ägna sig åt detta slags klassificeringar. Vad lär det oss om avvikelsens natur om det sätt varpå vi definierar avvikelsen - i detta fall extremism som en avvikelse från ideologier som tillhör den politiska mittfåran i samtida liberaldemokratier - enbart utgår från det faktum att de i vårt samhälle betraktas som avvikelser? Förutom att en sådan definition är tautologisk, säger den inte heller något om avvikelsens förhållande till den dominerande normen. Det vi dessutom, utifrån annan forskning om avvikelser (se t.ex. Becker 2006 [1963]), vet är att för att någon alls ska betraktas eller behandlas som avvikare så måste personen eller gruppen först "stämplas" som avvikare. Utifrån ett sådant perspektiv ses stämplingen, det vill säga utpekandet av någon som avvikare, som den sociala process som både skapar och vidmakthåller avvikelsen (vilken även kan bidra till att avvikaren förstärker de beteenden som anses vara avvikande).

Ett mer fruktbart perspektiv på dessa "avvikelsers" natur står Cas Mudde för. Som vi tidigare har sett gör han en distinktion mellan "extrema" och "radikala" politiska aktörer. Vid sidan av detta för han även ett intressant resonemang om extremism och radikalism som en "patologisk normalitet”. Muddes diskussion avser hur man ska förstå det han kallar populistiska radikalhögerpartier, deras agenda och eventuella politiska framgångar i förhållande till de uppfattningar som utmärker majoritetssamhället (Mudde 20IO). Den tidigare forskning som Mudde polemiserar mot har menat att dessa partier utgör en "normal patologi" i moderna demokratier, och med detta menat att de möjliggörs av det faktum att det finns en minoritet av medborgarna som hyser uppfattningar som i grunden avviker från den dominerande befolkningsmajoritetens och eliternas uppfattning. Mudde menar tvärtom att de föreställningar som möjliggjort framväxten av populistiska radikalhögerpartier står att finna i det moderna samhällets mest centrala normer och värderingar - men att dessa partier saluför en radikaliserad variant av vissa av 
dessa värderingar. Exempelvis pekar Mudde på hur föreställningen om nationen och det nationella är grundläggande för såväl moderna samhällens självförståelse som nationalstaters institutionaliserade praktiker. Pass, nationsgränser, nationella helgdagar och det faktum att sociala och demokratiska rättigheter främst garanteras genom ett nationellt medborgarskap kan tas som olika exempel på detta. Krav på att stänga gränser och skärpa kriterierna för medborgarskap innebär utifrån ett sådant perspektiv inte en avvikelse från normen, utan snarare en radikalisering av normen.

På ett liknande sätt skulle man kunna betrakta vänsterradikala partiers och rörelsers alternativa synsätt på demokratiska styrelseformer. Inom olika radikala vänsterrörelser - exempelvis sådana som utgår från anarkistiska eller rådskommunistiska idéer - har kritiken mot liberaldemokratins "blandade konstitution" ofta utgått från ett synsätt som ser direktdemokratiska styrelseformer som de mest eftersträvansvärda (se t.ex. Held I997, s. I85-I88). Utifrån den tidigare diskuterade Lucardies begreppsapparat skulle en sådan strävan ses som "demokratisk extremism”, i och med att den syftar till ett renodlat folkstyre som inte begränsas eller uppvägs av aristokratiska eller monarkiska former av makt. Betraktar man i stället sådana målsättningar utifrån Muddes resonemang om "patologisk normalitet", blir det snarare en fråga om en radikalisering av vissa aspekter av det moderna samhällets mest centrala normer och värderingar. På samma sätt som med nationen är demokratin grundläggande för moderna samhällens självförståelse som institutionaliserade praktiker. Krav på att medborgarna ska utöva sitt inflytande direkt i stället för genom valda ombud - genom alltifrån beslutande folkomröstningar till direktdemokratiska organ - blir utifrån ett sådant perspektiv också att betrakta som en radikalisering av den rådande normen.

I stället för att se "det politiskt extrema" som något som helt avviker från majoritetskulturen, ser Mudde det alltså som en radikal omtolkning av vissa av majoritetskulturens mest centrala element. Det faktum att sådana radikala omtolkningar leder till stora konflikter inom politik och samhälle - och till ett behov hos makthavare att stigmatisera de aktörer som framför dem - ses som ett uttryck för att dessa ifrågasätter etablerade tolkningar av hur politik och samhälle ska organiseras utifrån alternativa 
tolkningar av samhällets mest centrala värderingar. ${ }^{7}$ Hade "det politiskt extrema" i stället handlat om perspektiv som inte finner någon som helst klangbotten hos dessa centrala värderingar hade behovet av att använda makttekniker för att stigmatisera dem troligen varit mycket mindre.

\section{Gränsdragningar}

Som vi tidigare sett menar Backes att extremistbegreppet går att se som ett "stigmaord", vilket trots dess förmåga att nedvärdera andra används både politiskt och vetenskapligt. Med Backes egna formulering används sådana ord för att markera gränserna för det politiskt legitima (Backes 20IO, s. I78). Det är nu inte förvånande att den här typen av gränsdragningar görs. Inom såväl politik som forskning är gränsdragning mellan olika grupper, organisationer och fenomen av stor betydelse. För att exempelvis definiera ett vetenskapligt fält (i Bourdieus bemärkelse) eller ett politiskt verksamhetsområde blir gränser viktiga. "Vi arbetar med dessa frågor, men inte de där", kan en verksamhetsansvarig behöva säga för att visa vad det är de ska arbeta med. På samma sätt används gränsdragningar för att visa exempelvis vilka grupper, människor och organisationer som kan accepteras inom det politiska fältet. Det är emellertid

7. Samtidigt bör det betonas att dessa former av "radikaliseringar" varken på en intellektuell eller samhällelig nivå är fria från motsägelser och målkonflikter. Detta gäller i synnerhet när radikaliseringen gäller begrepp som nation och demokrati. Den amerikanske sociologen Michael Mann diskuterar exempelvis i sin bok The Dark Side of Democracy. Explaining Ethnic Cleansing (2005) det moderna fenomenet "etnisk rensning" som resultatet av en konflikt som finns inneboende i själva demokratibegreppet, såsom det kommit att förstås i en värld där nationer ofta betraktas som en förutsättning för demokratins förverkligande. Konflikten består i att folkstyrets folk å ena sidan har setts som "demos", det vill säga de medborgare som under jämlika former gemensamt utövar makt, å andra sidan har setts som "etnos", det vill säga de som tillhör en specifik etnisk grupp eller en "nation". Mann menar att det är i situationer då demokrati främst förståtts utifrån "etnos" som ohyggliga övergrepp som etnisk rensning har kunnat uppkomma även i demokratier. Historiska erfarenheter av sådana övergrepp (i synnerhet Nazityskland) har också legat till grund för att demokrati i dag inte enbart betraktas som "folkstyre" (såsom hos Aristoteles) eller majoritetens styre. Minst lika viktigt för en rad demokratidefinitioner är även att minoriteter och andra utsatta grupper kan garanteras grundläggande medborgerliga och mänskliga rättigheter, och att dessa rättigheter inte kan åsidosättas av befolkningsmajoritetens beslut. 
intressant att diskutera hur dessa gränsdragningar går till, och på vilket sätt politik och vetenskap kan använda varandra för att främja sina respektive intressen.

Sociologen Thomas Gieryn (1983) tar sig an gränsdragningar i termer av "gränsdragningsarbete" (boundary-work) för att beskriva hur forskare konstant arbetar med att avgränsa "forskning" från andra intellektuella verksamheter. Det som skiljer forskning från andra kunskapsrelaterade verksamheter är enligt det här perspektivet inte något essentiellt, utan skillnaden skapas genom forskarvärldens egna aktiviteter. Gieryns tes är att det är viktigt för forskare att avgränsa forskning från icke-forskning, i syfte att uppnå egna professionella mål, som intellektuell auktoritet och karriärmöjligheter, att erhålla ökade resurser, men även att skydda den vetenskapliga forskningens autonomi från politiska ingrepp. Med Gieryns terminologi skapar gränsdragningsarbetet en ideologisk stil genom vilken "det vetenskapliga" skiljs från det icke-vetenskapliga samtidigt som det första framställs i bättre dager än det andra.

Begreppet "gränsdragningsarbete" har utvecklats och diskuterats i olika sammanhang. David Guston använder begreppet för att analysera relationen mellan forskning och politik. Ett av hans bidrag är att peka på att vissa organisationer fungerar som aktörer för att dra dessa gränser, de är "gränsorganisationer" (boundary organizations) (Guston 200I). Dessa organisationer existerar i skarven mellan olika typer av världar, exempelvis "politik" respektive "forskning", och de försöker brygga över olika världar och göra bägge nöjda genom vad Sheila Jasanoff (I990) har kallat för "samproduktion" (co-production), i betydelsen samtidigt skapande av kunskap och social ordning. De underlättar samarbete mellan forskare och icke-forskare samtidigt som de skapar en kombinerad vetenskaplig och social ordning där "gränsobjekt" (boundary objects) skapas och upprätthålls. Dessa objekt kan exempelvis vara i form av regler, organisationer eller institutioner och kan användas av bägge sidor om gränsdragningsorganisationen.

Vi menar att det är möjligt och fruktbart att se begreppet "extremism” som ett gränsobjekt. Det gör det möjligt att förstå hur olika aktörer kan komma överens om nyttan och centrala förståelser av ett begrepp. Sett ur det perspektivet är extremismbegreppet en term som 
används av vissa experter, journalister och politiker för att sätta gränser för, eller i forskarnas fall att analysera, vilken typ av politik som ska anses som acceptabel. Användningen av termen skapar ett slags stabilitet mellan dessa aktörer genom deras gemensamma acceptans av begreppet. Dess gränser är för den skull inte givna, men stabiliteten upprätthålls i det gemensamma skapandet av begreppets tillfälliga och kontextbundna innehåll. Ett uppenbart exempel på detta är hur begreppet "extremism" under 1970-talet fick en central roll i Västtysklands förståelse och tilllämpning av landets författningsskydd. Under förbundsrepublikens tidiga år fanns ingen entydig och allmänt accepterad terminologi för att särskilja aktörer som hotade författningen från aktörer som avvek radikalt från dominerande uppfattningar men inte hotade författningen. Backes (20IO, s. I40 ff.) beskriver hur politiker, myndigheter, journalister och akademiker sedermera kom att bidra till att etablera en förståelse som såväl rättsligt och administrativt som i offentliga debatter kunde användas för att till exempel särskilja " extremism" från "radikalism”. I ett annat sammanhang vore det värdefullt att empiriskt analysera på vilket sätt "extremism" har kommit att bli ett gränsobjekt i Sverige, och undersöka hur politik, journalistik och vetenskap förhållit sig till varandra och eventuellt gett varandra legitim status.

Samtidigt ska framhållas att Gieryn i sin karakteristik av "gränsdragningsarbete" menar att detta även kan syfta till att värna den vetenskapliga forskningens autonomi från politiska ingrepp. I detta sammanhang skulle det kunna innebära att forskare avvisar begreppet "extremist", eftersom det främst används för att stigmatisera politiska avvikelser, och i sig - vilket framgått i denna artikel - inte erbjuder några vetenskapliga förklaringar till varför sådana avvikelser uppkommer. Medan politikens kunskapsintressen främst syftar till maktutövning, syftar samhällsvetenskap till att förklara och begripliggöra samhällsfenomen. Den här artikeln är i sig ett exempel på ett sådant gränsdragningsarbete, där vi ställer forskningens analytiska kunskapsintressen och autonomi i relation till politik och myndighetsutövning. 


\section{"Extremism" i politiken}

Backes försök att skapa en hållbar definition av "extremism" illustrerar inte bara svårigheten att skapa ett generaliserbart och icke-normativt vetenskapligt begrepp för detta samhällsfenomen. Det visar också på de problem som drabbar den som i en liberaldemokratisk rättsstat vill genomföra åtgärder utifrån en uttömmande definition av "extremism", samtidigt som grundlagsfästa rättigheter för att bilda opinion och påverka samhället respekteras. Det är sådana problem som exempelvis fått den svenska staten att tidigare ställa sig skeptisk till regelrätta förbud av organisationer som uttrycker vissa åsikter. I stället har lagar till skydd för demokratin främst handlat om att förbjuda politiskt motiverade handlingar som direkt hotar andra medborgare och deras mänskliga eller medborgerliga rättigheter, till exempel hets mot folkgrupp och annan form av diskrimineringslagstiftning, olika former av högmålsbrottslagar riktade mot individer eller grupper som med våld eller tvång vill förhindra medborgare från att utöva sina politiska rättigheter eller folkvalda från att fullgöra sin maktutövning (se t.ex. SOU 2000:88).

Även om man väljer en enklare definition av "extremism” än Backes, och definierar det som grupper som har anti-demokratiska åsikter och/ eller använder anti-demokratiska metoder, uppstår en rad problem i hur konkreta bedömningar ska göras av myndighetspersoner. Vår diskussion i denna artikel har främst fokuserat på begreppets problematiska sidor i ett vetenskapligt sammanhang, men man skulle kunna tänka sig en rad olika typer av aktörer som av samma skäl blir problematiska att klassificera även i ett myndighetsutövningssammanhang.

Efter vår genomgång av extremistbegreppet och de problem som det är förbundet med, kan man naturligtvis också fråga sig vilka de mer fruktbara alternativen till detta begrepp är inom ett vetenskapligt sammanhang. Även om denna fråga skulle kräva en mer uttömmande diskussion, är det övergripande svaret på den att detta är helt beroende vilka samhällsvetenskapliga frågeställningar vi talar om. Talar vi till exempel om parti- och rörelseforskningens behov av att etikettera sina studieobjekt, är alternativen uppenbara. Bredare partigrupper brukar vanligen namnges utifrån de ideologiska traditioner som håller dessa grup- 
per samman. Även om detta blir mer problematiskt för partier som inte vill sammankopplas med dessa traditioner tycks det ändå mer rimligt att välja sådana benämningar i stället för enbart stigmatiserande termer. Samma sak gäller sociala rörelser. Vill man undersöka nazistiska eller nyfascistiska grupperingar, kan man benämna dem på det sättet. Givetvis går även sådana benämningar till viss del att se som relativa den tid och plats som de används för. Men oavsett sådan empirisk variation hänvisar sådana benämningar till specifika idé- och rörelsetraditioner, som innehåller någon form av substans. Begreppet extremist anger däremot enbart att en grupp avviker från majoritetssamhällets och de politiska eliternas normer, oavsett vilka dessa avvikande normer är.

Finns det i stället ett behov av att beskriva de typer av förändringsdynamik eller ömsesidigt betingande relationer och konflikter som ofta inbegriper sociala rörelser, politiska partier och staten i moderna samhällen, kan begrepp som "radikal" eller "radikalisering" fungera bättre. Till exempel handlar Muddes (20I0) förståelse av "radikal" om hur vissa politiska aktörer har anammat en mer radikal tolkning av de värderingar som är centrala i ett givet samhälle, vilket visar på en mer relationell förståelse av politiska "avvikelser". Inom annan forskning ses i stället "radikalisering" som en relationell process vars utfall påverkas av en rad aktörers agerande, vilket kan innefatta sociala rörelser, politiska partier, staten och rörelsernas motståndare (se t.ex. della Porta 20I3; Alimi m.fl. 20I5) ${ }^{8}$ En sådan ansats syftar snarare till att förklara hur olika ömsesidigt betingade handlingar bidrar till - eller motverkar - att rörelseaktörer i vissa situationer övergår till politisk våldsanvändning. Därmed lägger den mindre vikt vid dessa aktörers ideologiska inriktning, och ser mer till de metoder som aktörerna använder.

Vår slutsats är att ordet extremism överlag bör användas i medvetenhet om dess relativistiska och stigmatiserande karaktär. Det bidrar främst till att skapa gränser för det som i samtiden anses vara politiskt legitimt. Det är inte ett analytiskt begrepp som kan användas till att förklara varför

8. Det bör noteras att även begreppen "radikal" och "radikalisering" är omtvistade inom forskningen. De källor vi här anger avser främst forskning om sociala rörelser. För en översikt och diskussion om olika betydelser inom andra forskningsfält, se t.ex. Sedgwick (2010). 
vissa personer dras till vissa idéer och aktiviteter. Det är ett begrepp för att typologisera och gruppera, grundat $i$ en föreställning om avvikelser från en viss politisk normalitet. Det kan givetvis vara statens - och ibland kanske till och med forskningens - uppgift att göra detta, men det bör som vi ser det göras med intresse att också förstå uppkomsten och därefter motverka det som uppfattas som problematiskt.

\section{Referenser}

Adorno, Theodor W. (red.) 1950. The Authoritarian Personality. New York: Harper.

Alimi, Eitan Y., Bosi, Lorenzo \& Demetriou, Chares 20I5. The Dynamics of Radicalization. A Relational and Comparative Perspective. New York: Oxford University Press.

Arendt, Hannah 2016 [195I]. Totalitarismens ursprung. Göteborg: Daidalos.

Backes, Uwe 2006. Politische Extreme. Eine Wort- und Begriffseschichte von der Antike bis in die Gegenwart. Göttingen: Vandenhoeck \& Ruprecht.

Backes, Uwe 2oro. Political Extremes. A Conceptual History from Antiquity to the Present. London: Routledge.

Becker, Howard S. 2006 [1963]. Utanför. Avvikandets sociologi. Lund: Arkiv förlag.

della Porta, Donatella 2013. Clandestine Political Violence. New York: Cambridge University Press.

Dir. 2OI4:IO3. En nationell samordnare för att värna demokratin mot våldsbejakande extremism. Beslut vid regeringssammanträde den 26 juni 2014.

Gieryn, Thomas F. 1983. "Boundary-Work and the Demarcation of Science from NonScience. Strains and Interests in Professional Ideologies of Scientists", American Sociological Review, 48, 6, s. 78I-795.

URL: http://www.jstor.org/stable/2095325

Guston, David H. 20oI. "Boundary Organizations in Environmental Policy and Science. An Introduction", Science, Technology \& Human Values, 26, 4, s. 399-408. DOI: http://dx.doi.org/IO.II77/or6224390I0260040I

Held, David 1997. Demokratimodeller. Från klassisk demokrati till demokratisk autonomi. 2 uppl. Göteborg: Daidalos.

Jasanoff, Sheila 1990. The Fifth Branch. Science Advisers as Policymakers. Cambridge: Harvard University Press.

Jesse, Eckhard \& Thieme, Tom (red.) 20Ir. Extremismus in den EU-Staaten. Wiesbaden: VS Verlag.

Klingemann, Hans-Dieter \& Pappi, Franz U. 1972. Politischer Radikalismus. München: Oldenbourg.

Lipset, Seymour Martin \& Raab, Earl 1970. The Politics of Unreason. Right-Wing Extremism in America, I790-1970. London: Heinemann.

Lucardie, Paul 20I4. Democratic Extremism in Theory and Practice. All Power to the People. Abingdon, Oxon: Routledge. 
Mann, Michael 2005. The Dark Side of Democracy. Explaining Ethnic Cleansing. New York: Cambridge University Press.

March, Luke 20II. Radical Left Parties in Europe. London: Routledge.

March, Luke \& Mudde, Cas 2005. "What's Left of the Radical Left? The European Radical Left Since 1989. Decline and Mutation", Comparative European Politics, 3, I, s. 23-49.

DOI: http://dx.doi.org/Io.I057/palgrave.cep.6II0052

Mouffe, Chantal 2008. Om det politiska. Hägersten: Tankekraft.

Mudde, Cas 20Io. ”The Populist Radical Right. A Pathological Normalcy”, West European Politics, 33, 6, s. II67-II86 (en tidigare version av denna artikel finns i sv. övers. som "Den populistiska radikalhögern. En patologisk normalitet” i Fronesis nr 34 20IO).

DoI: http://dx.doi.org/IO.IO80/OI402382.2010.50890I

Sedgwick, Mark 20Io. "The Concept of Radicalization as a Source of Confusion", Terrorism and Political Violence, 22, 4, s. 479-494.

DOI: http://dx.doi.org/Io.I080/09546553.2010.491009

SOU 2000:88. Organiserad brottslighet, hets mot folkgrupp, hets mot homosexuella, m.m. Straffansvarets räckvidd, betänkande av Kommittén om straffansvar för organiserad brottslighet, m.m. Stockholm: Fritzes.

SOU 2013:81. När vi bryr oss. Förslag om samverkan och utbildning för att effektivare förebygga våldsbejakande extremism, betänkande av Utredningen om ett effektivare arbete för att förebygga våldsbejakande extremism. Stockholm: Fritzes. 


\section{Moderna klassiker}

\begin{tabular}{c}
\hline Marie Jahoda \\
\hline Paul F. Lazarsfeld, Hans Zeisel \\
\hline De arbetslösa i Marienthal \\
\hline
\end{tabular}

\section{Arkiv förlag}

De arbetslösa $i$ Marienthal (Die Arbeitslosen von Marienthal) från I933 av Marie Jahoda, Paul F. Lazarsfeld och Hans Zeisel är ett av samhällsvetenskapens mest legendariska arbeten. $\mathrm{Nu}$ finns den för första gången på svenska. Marienthalstudien lade grunden till mycket av dagens arbetslöshetsforskning och var banbrytande i sitt sätt att kombinera kvalitativa och kvantitativa data på ett sätt som fortfarande inspirerar. En inledning av den österrikiske sociologen Christian Fleck och ett efterord av den svenske sociologen Paavo Bergman presenterar verket och dess betydelse för samhällsvetenskapen.

Översättning Svenja Hums Arkiv förlag, I90 sidor 